\title{
The Effect of Leadership, Work Motivation and Work Satisfaction on Performance of Employees of Education and Culture Department in Padang Pariaman
}

\author{
Enny Noviyanti ${ }^{1}$, Efrizal Syofyan ${ }^{2}$, Susi Evanita ${ }^{3}$ \\ ${ }^{1}$ Universitas Negeri Padang, Padang, Indonesia, $\square$ ennynoviyanti04@gmail.com \\ ${ }^{2}$ Universitas Negeri Padang, Padang, Indonesia, $\triangle$ efrizal_syofyan@yahoo.com \\ ${ }^{3}$ Universitas Negeri Padang, Padang, Indonesia, $\square$ susievanita@gmail.com
}

\begin{abstract}
This study aims to examine the effect of leadership, motivation, and job satisfaction on the performance of education and culture department employees of Padang Pariaman Regency. The sampling technique used is by using the proportional stratified random sampling method. The questionnaire was distributed to 112 employees of the Padang Pariaman District Education and Culture Department. Data were analyzed using Path Analysis and processed with SPSS 16.00. The results show that leadership has a significant effect on work motivation, leadership does not have a significant effect on job satisfaction, work motivation has a significant effect on job satisfaction, leadership does not have a significant influence on performance, work motivation has a significant effect on job performance and satisfaction significantly influence performance employee of the Padang Pariaman District Education and Culture Department.
\end{abstract}

Keywords: leadership, motivational work satisfaction, performance

\section{Introduction}

The Padang Pariaman District Education and Culture Office has an interest in the best performance that can be produced by the applicable system in the organization. Human Resource Management is one of the key factors to get the best performance, because in addition to dealing with problems such as employee absenteeism, skills, and expertise. HR management is also obliged to build employee conducive behavior to get the best performance.

In an effort to empower employees and employee development, managerial parties, in this case, the Head of the Department of Education and Culture always try to carry out management functions with the aim of achieving the goals. Manage by providing facilities and infrastructure where management seeks to improve the quality of work of employees and provide encouragement for employees to always innovate and create, including creating a fair and flexible structure system with clear and humane division of tasks, authorities, and responsibilities and paying attention to the ability of employees and its efforts in improving its performance from time to time. Employee performance must be improved, taking into account all aspects or factors that can influence it. Given the many factors that affect employee performance, the authors limit the factors that influence performance are leadership, work motivation, and job satisfaction.

Performance

According to Hasibuan (2001: 94) is a result of work achieved by someone in carrying out the tasks assigned to him based on skills, experience, and sincerity of time. Next Handoko (2001: 75) states that performance is a picture of one's success in doing something. According to Mangkunegara (2001: 67) performance is the result of work in quality and quantity achieved by an employee in carrying out his duties in accordance with the responsibilities given to him.

Employee performance influences how much they contribute to the organization, including output quantity, output quality, output period, attendance at work and cooperative attitude (Mathis and Jackson, 2002). Prawirosentono (2012: 120) states that performance is the result of work that can be achieved by a person or group of people in an organization, in accordance with their respective responsibilities and authorities in an effort to achieve organizational goals. Wibowo (2011) gives an 
understanding of performance as a result of work or work performance, but actual performance has a broader meaning, not only work but also including how the work process takes place.

Syafii et al (2015) in his research showed that employee performance is influenced by several factors, namely (1) organizational culture; (2) leadership style; and (3) employee motivation (Olusadum and Anulika, 2018; Qatmeemalmarhoon et al., 2017). Whereas according to Zameer et al (2014) the factors that influence performance are: job knowledge, output quality, and quantity, leadership ability, supervision, dependence, cooperation, assessment, versatility. Khairiyah and Annisa (2013) in their research showed that performance was influenced by (1) job satisfaction, (2) leadership style, and (3) work motivation.

\section{Leadership}

Handoko (2003: 27) argues that leadership is the ability someone has to influence other people to work towards their goals and objectives. Rivai and Sagala (2009: 270) explain that leadership is an influencing process in determining the goals of an organization or agency, motivating followers' behavior to achieve goals, influencing to improve follower culture, and directing processes into positive activities that have to do with work in the organization or agency. According to Robbins (2006: 127) leadership is the ability to influence a group to achieve goals. Furthermore, according to Thoha (2003: 262) leadership is an activity to influence the behavior of others or art influences human behavior both individuals and groups.

According to de Jong and Hartog (2007), leadership can be defined as the process of influencing people to get the desired results. Sharma and Jain (2013) state that leadership is a process in which someone influences others to achieve goals and direct them in ways that make them more cohesive and coherent. Furthermore, Yusuf-Habeeb and Ibrahim (2017) stated that leadership is a process of social influence that seeks to gain cooperation and individual support for the actualization of several objectives. Whereas according to Gharibvand (2012) defining leadership is how leaders communicate in general and relate to people, the way leaders motivate and train subordinates and the way leaders provide direction to their teams to carry out their duties.

\section{Work Motivation}

According to Asa'ad (2002: 45), work motivation is something that gives rise to enthusiasm or work motivation. Whereas according to Robbins (2006: 166) work motivation is defined as the willingness to issue a high level of effort for the goals of the organization or agency that is conditioned by the ability of that effort to meet individual needs. According to Martoyo (2007: 106), work motivation is something that raises encouragement or morale. Work motivation is intended to provide stimulant power to the employee concerned so that the employee works with all the power and effort (Manulang, 2002: 56). According to Azar and Shafighi (2013), motivation is an internal state and strength, which encourages individuals to take certain actions. Furthermore, Shahzadi et al (2014) define motivation basically as a means of facilitating behavior change.

\section{Job Satisfaction}

Simamora (2005: 85) suggests that job satisfaction is a set of employee feelings about whether or not their work is pleasant. Mathis and Jackson (2002: 241) state that satisfaction is a positive emotional state from evaluating one's work experience. Job dissatisfaction will arise when these expectations are not met. According to Rivai and Sagala (2009: 301) job satisfaction is an assessment of work about how far the overall work satisfies their needs. Job satisfaction is a measure of the rate at which employees are satisfied and happy with their work (Dawal et al., 2009).

Ali et al. (2016) state that job satisfaction is an emotional answer to work and the social and physical situation of the work environment. Job satisfaction refers to the feeling of one's satisfaction at work, which acts as a motivation to work (Munir et al., 2016). Job satisfaction is related to the degree to which people like their work (Spector in Yuen et al., 2018). Job satisfaction refers to employees' attitudes or opinions about the work itself or the relevant environment and their overall emotional response to their work role and is one indicator of happiness (Ouyang et al., 2015).

Hasibuan (2008: 203) states that employee job satisfaction is influenced by the following factors: (1) fair and decent service, (2) appropriate placement in accordance with expertise, (3) the severity of the 
work, (4) atmosphere and work environment, (5) equipment that supports the implementation of work, (6) leadership, (7) the nature of monotonous or not work and (8) work motivation.

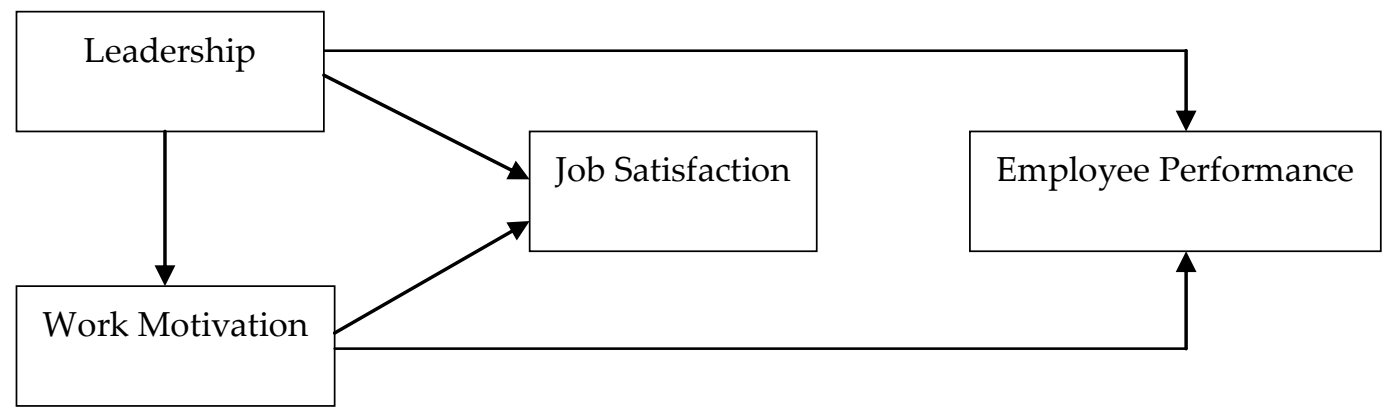

Figure 1 Conceptual Framework

\section{Hypothesis}

Leadership is the ability to influence the behavior of a person or group of people to achieve certain goals in certain situations. With this ability, the leader can influence employee work motivation. Alghazo and Al-Anazi (2016) found that there was a strong relationship between leadership style and employee motivation. Syafii et al (2015) showed that leadership style had a significant effect on employee motivation. Khuong and Hoang (2015) show that charismatic leadership, relationshiporiented leadership, and ethnic-based contingent reward leadership are positively related to employee motivation. Mehta et al. (2003) showed that leadership style consisting of participatory leadership style, supportive leadership style, and directive leadership style had a significant positive impact on motivation.

H1: Leadership has a significant effect on work motivation.

Good and effective leadership will be able to increase employee motivation so that ultimately it will create job satisfaction. Raimonda et al. (2015) which shows that leadership has a positive effect on job satisfaction. Zhonghua et al. (2016) also found that leadership has a positive effect on job satisfaction. Profita et al (2017) show that leadership influences job satisfaction.

H2: Leadership has a significant effect on job satisfaction.

Motivation is something that encourages individuals to work seriously and direct employees to reach a different future from now to achieve a predetermined task. Karsh and Iskender (2009) revealed that motivation levels affect job satisfaction, where high motivation leads to high job satisfaction, and low motivation leads to low job satisfaction. Adrian et al. (2009) also found that work motivation had a positive effect on job satisfaction. Profita et al (2017) show that motivation influences job satisfaction. Suttikun et al. (2018) show that employees will have increased motivation if they believe their hard work will produce the desired results. If the desired results are met, the motivation cycle continues and job satisfaction increases.

H3: Work motivation has a significant effect on job satisfaction.

Leaders can encourage someone and motivate each employee so that it will affect employee performance. Veliu et al. (2017) which shows that democratic, autocratic and transformational leadership positively influences employee performance. Salutondok and Soegoto (2015) also found that leadership had a positive and significant effect on employee performance. Kemby et al. (2017) show that leadership has a significant effect on performance.Profita et al (2017) show that leadership influences employee performance.

H4: Leadership has a significant effect on performance.

Employees who have high work motivation usually have high performance too. Azar and Shafighi (2014) showed that work motivation has a positive and significant influence on employee job performance. Shahzadi et al. (2014) found that there was a significant and positive relationship between employee motivation and employee performance. Fachreza et al. (2018) show that work 
motivation has a significant and positive effect on employee performance. Rumondor et al. (2016) found that motivation had a positive and significant effect on employee performance.

H5: Work motivation has a significant effect on performance.

Job satisfaction is a feeling of satisfaction that someone feels towards his job. Job satisfaction can affect employee performance, where employees who work in accordance with the desired goals and feel satisfied with their work, in the end, he will be able to improve overall performance achievements. Khairiyah and Annisa (2013) who found job satisfaction had a significant effect on employee performance. Profita et al (2017) show that job satisfaction influences employee performance. Rahmadita and Susilatri (2004) found that job satisfaction affects employee performance. Rumengan (2011) shows job satisfaction has a direct, positive and significant effect on performance.

H6: Job satisfaction has a significant effect on performance.

\section{Methods}

\section{Measurement}

Respondents were asked to fill out or respond to the questionnaire given by giving a checklist to one of the alternative answers. The answers to each question item use a 5-point Likert scale $(1=$ strongly disagree, $5=$ strongly agree). Leadership is measured using indicators adopted from Roring (2017). Work motivation is measured using indicators adopted from Gondokusumo and Sutanto (2015). Job satisfaction is measured using indicators adopted from Gondokusumo and Sutanto (2015). And performance is measured using indicators adopted from Profita et al. (2017).

\section{Sample}

Respondents in this study were education and culture department employees of Kabupaten Padang Pariaman. The sampling technique used in this study was the proportional stratified random sampling method. The questionnaire was distributed to 112 employees of the Padang Pariaman District Education and Culture Office. Data were analyzed using BerJalurganda Linear Regression Analysis. Determination of the number of samples in this study is by using the Slovin formula.

\section{Results and Discussion}

All statements used in this study are valid. And the Cronbach Alpha value for each variable is also high, all above 0.6. The data in this study also passed the classical assumption test. This shows that all data is feasible to be tested.

\section{Sub Structure 1 (Relationship of Leadership to Work Motivation)}

Contributions or contributions to the influence of leadership on work motivation are $7.4 \%$. It is known that the significance value of the leadership variable which is 0.004 is smaller than 0.05 . While the value of the path coefficient for other variables outside the study is e $1=\sqrt{ }((1-0,074))=0,926$.

The influence of leadership and work motivation on job satisfaction is $46.3 \%$. While for the value of the path coefficient for other variables outside the study is $\varepsilon 2=\sqrt{ }((1-0,463))=0.537$. The significance value of the leadership variable is 0.348 greater than 0.05 and the significance of the motivation variable is 0.000 less than 0.05 . This gives the conclusion that leadership does not have a significant effect on job satisfaction while work motivation has a significant effect on job satisfaction of the Department of Education and Culture, Padang Pariaman.

The amount of contribution or contribution to the influence of leadership, work motivation, and job satisfaction on performance is $34.1 \%$. While the value of the path coefficient for other variables outside the study is adalah3 $=\sqrt{ }((1-0.341))=0.659$. The significance value of the leadership variable which is 0.753 is greater than 0.05 and the significance of the motivation variable is 0.001 smaller than 0.05 , then the significance of the job satisfaction variable is 0.014 smaller than 0.05 . This gives the conclusion that work motivation and job satisfaction individually have a significant effect on the performance of education and culture department employees, Padang Pariaman.While leadership does not have a significant effect on the performance of employees of the Department of Education and Culture, Kab.Padang Pariaman. 
So that the structure of the causal relationship between variables can be seen in the following figure.

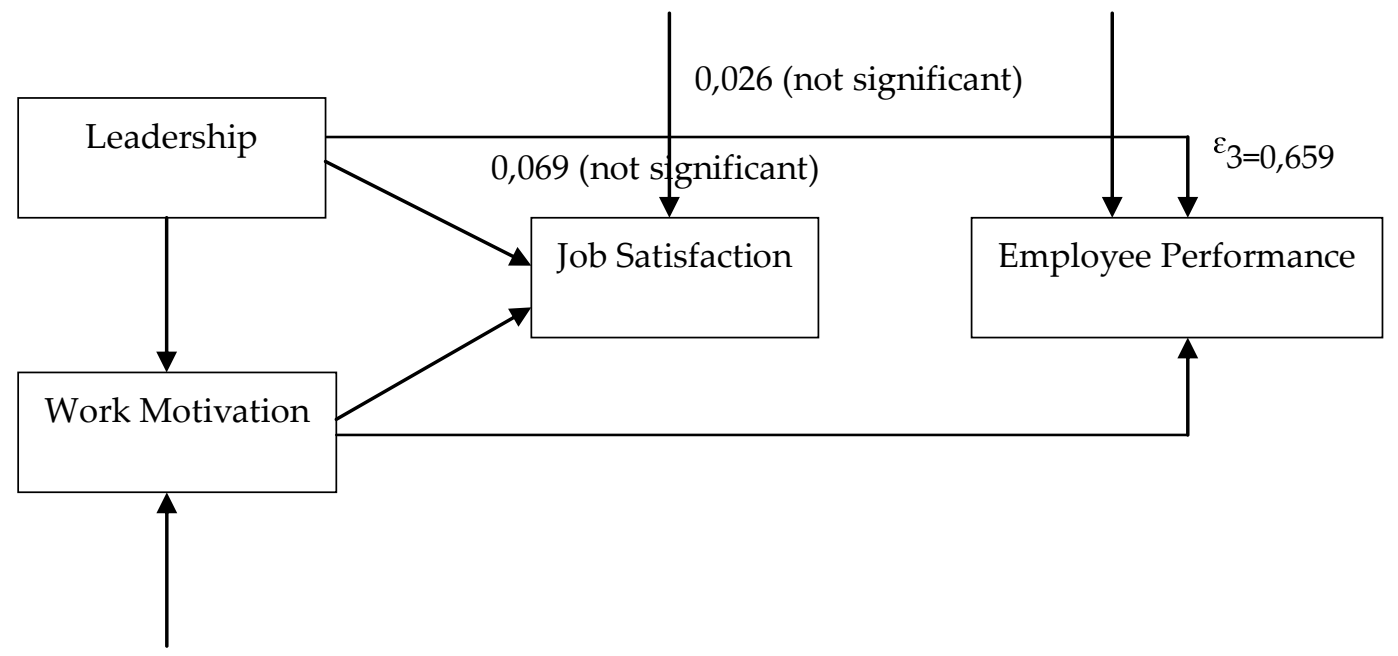

Figure 2 Relationship Structure and Effects of Variable Causes on Performance

\section{Effect of Leadership Through Satisfaction with Performance.}

Leadership, both directly and indirectly, was found to have no effect on the performance of employees of the Department of Education and Culture, Padang Pariaman. This is because the value of leadership significance for work performance and satisfaction is above 0.05 , which is 0.753 and 0.348 .

But leadership can influence performance through motivation. It is known that the leadership beta value for performance is 0.026 . While the indirect effect of leadership through work motivation on performance is the multiplication of the beta value of leadership on performance with beta values of work motivation on performance, which is $0.026 \times 0.361=0.009$. So the total influence given by leadership to performance is a direct effect plus indirect influence, which is $0.026+0.009=0.035$. Based on the results of these calculations, it is known that the value of indirect influence is greater than the value of direct influence. These results indicate that indirectly leadership through work motivation has a significant influence on the performance of employees of the Department of Education and Culture, Padang Pariaman.

\section{Effect of Work Motivation Through Job Satisfaction on Performance.}

It is known that the direct effect of work motivation on performance is 0.361 . While the indirect effect of work motivation through job satisfaction on performance is the multiplication of beta values of work motivation on performance with a beta value of job satisfaction on performance, which is $0.361 \times 0.266=0.096$. Then the total effect given by work motivation on performance is a direct effect plus indirect influence, namely $0.361+0.096=0.457$. Based on the results of these calculations, it is known that the value of indirect influence is greater than the value of direct influence. These results indicate that indirectly work motivation through job satisfaction has a significant influence on the performance of education and culture department employees of Padang Pariaman.

\section{Relationship between Leadership and Work Motivation}

This study shows that direct leadership has a significant effect on the work motivation of employees of the Department of Education and Culture, Padang Pariaman. This is indicated by the significance value of the leadership variable, which is 0.004 smaller than 0.05 .

Leadership can be interpreted as the ability of a leader to be able to move and encourage subordinates to apply and act in accordance with the objectives to be achieved. The leader must also be fair to his subordinates and must be able to foster good relations with subordinates. If a leader can provide a good example to subordinates, then this will be a motivation for subordinates to work as well as possible and improve achievement. 
This finding is in line with the research conducted by Alghazo and Al-Anazi (2016) who found that there was a strong relationship between leadership style and employee motivation. Syafii et al (2015) showed that leadership style had a significant effect on employee motivation. Khuong and Hoang (2015) show that charismatic leadership, relationship-oriented leadership, and ethnic-based contingent reward leadership are positively related to employee motivation. Mehta et al. (2003) showed that leadership style consisting of participatory leadership style, supportive leadership style, and directive leadership style had a significant positive impact on motivation.

\section{Relationship between Leadership and Job Satisfaction}

This study proposes that leadership has a significant effect on job satisfaction. Good and effective leadership will be able to increase employee motivation so that ultimately it will create job satisfaction. Effective and dynamic leadership that is shown by a leader is the dominant element in determining the likelihood of success of employee duties. Effective leadership tends to encourage a leader to study the work motivation of each employee so that leadership in accordance with the characteristics of the employee can be applied and will ultimately affect employee job satisfaction.

However, the processed data in this study shows that direct leadership does not have a significant effect on job satisfaction of the District Education and Culture Office staff. Padang Pariaman. This is indicated by the significance value of the leadership variable which is 0.348 greater than 0.05 . This finding is contrary to research from Raimonda et al. (2015) which shows that leadership has a positive effect on job satisfaction. Zhonghua et al. (2016) also found that leadership has a positive effect on job satisfaction. Profita et al (2017) show that leadership.

\section{Relationship between Work Motivation and Job Satisfaction}

This study shows that work motivation directly affects significantly the job satisfaction of the Education and Culture Office staff of Padang Pariaman. This is indicated by the significance value of the motivation variable which is 0,000 less than 0.05 .

Motivation is a stimulating tool that drives and drives aimed at employees so that employees can do a job in accordance with the objectives to be achieved. These stimuli can be given in the form of appreciation to employees for the achievements of the organization. So that the award will further encourage them to work harder and improve their abilities in the future. Motivation results in high morale, namely a positive attitude towards the work organization of leaders and coworkers. If high work motivation is owned by an employee, satisfaction will arise in the work. If employee job satisfaction has been achieved, job performance will be created.

This finding is in line with previous research by Karsh and Iskender (2009) which revealed that motivation levels affect job satisfaction, where high motivation leads to high job satisfaction, and low motivation leads to low job satisfaction. Adrian et al. (2009) also found that work motivation had a positive effect on job satisfaction. Profita et al (2017) show that motivation influences job satisfaction. Suttikun et al. (2018) show that employees will have increased motivation if they believe their hard work will produce the desired results. If the desired results are met, the motivation cycle continues and job satisfaction increases. Saleem et al. (2010) found that there was a positive relationship between motivation and job satisfaction. Ali et al. (2016) found that motivation has a positive effect on job satisfaction. Anghelache (2015) in his research shows that there is a lack of correlation between motivation and job satisfaction. In general, employees need a high initial level of motivation, but in time job satisfaction tends to decrease.

\section{Relationship between Leadership and Performance}

This study proposes that leadership has a significant effect on performance. Effective and dynamic leadership that is shown by a leader is the dominant element in determining the likelihood of success of employee duties. Leaders can encourage someone and motivate each employee so that it will affect employee performance.

However, this research shows that direct leadership does not have a significant effect on the performance of employees of the Department of Education and Culture, Padang Pariaman. This is indicated by the significance value of the leadership variable which is 0.753 greater than 0.05 . This finding contradicts previous research by Veliu et al. (2017) which shows that democratic, autocratic 
and transformational leadership positively influences employee performance. Salutondok and Soegoto (2015) also found that leadership had a positive and significant effect on employee performance. Kemby et al. (2017) show that leadership has a significant effect on employee performance.Profita et al (2017) show that leadership influences employee performance.

But the results of this study are in line with the study conducted by Rumondor et al. (2016) found that leadership did not significantly influence employee performance. Khairiyah and Annisa (2013) also found that leadership style did not significantly influence employee performance. Haryanto (2017) found that leadership style did not have a positive and insignificant effect on employee performance. Handoyo et al. (2015) also found that transformational leadership and transactional leadership did not significantly influence employee performance. Muhlis (2014) in his research showed that leadership does not affect employee performance.

This study found leadership can influence performance through work motivation. Handoyo et al. (2015) also prove that transformational leadership has a negative effect on employee performance through work motivation, then transactional leadership is also found to have a positive impact on employee performance through work motivation. The study conducted by Muhlis (2014) also found that leadership indirectly had a positive and significant effect on performance through motivation.

This can happen because the majority of respondents in this study are those with an age range and those who have worked more than 20 years of service. They assume that they are people who must be elder, people who have long worked in the field so that someone's leadership no longer influences their performance.

\section{Relationship between Work Motivation and Performance}

This study shows that work motivation directly affects significantly the performance of employees of the Department of Education and Culture, Padang Pariaman. This is indicated by the significance value of the motivation variable which is 0.001 smaller than 0.05 .

Motivation is a skill in directing employees to organizational goals to want to work and try so that the desires of employees and organizational goals can be achieved. The motivation for someone to do a job is because of a life necessity that must be fulfilled. This need can be in the form of economic needs, namely to obtain money, while non-economic needs can be interpreted as the need to gain more appreciation and desire.

With all of these needs, someone is required to be more active and active in work, to achieve this there is a need for motivation in doing work because it can encourage someone to work and always want to continue their business. Therefore if employees who have high work motivation usually have high performance too.

This finding is in line with previous research by Azar and Shafighi (2014) which showed that work motivation has a positive and significant influence on employee job performance. Shahzadi et al. (2014) found that there was a significant and positive relationship between employee motivation and employee performance. Fachreza et al. (2018) show that work motivation has a significant and positive effect on employee performance. Rumondor et al. (2016) found that motivation had a positive and significant effect on employee performance.

Furthermore, Kemby et al. (2017) also found that motivation has a significant effect on employee performance. Profita et al (2017) show that motivation affects employee performance.Setiadi et al. (2016) show that work motivation has a significant effect on employee performance. Syafii et al. (2015) also found that employee motivation had a significant effect on employee performance.

Relationship between Job Satisfaction and Performance

This study shows that job satisfaction directly has a significant effect on the performance of employees of the Department of Education and Culture, Padang Pariaman. This is indicated by the significance value of the job satisfaction variable which is 0.014 smaller than 0.05 .

Employees who feel satisfied with work usually work harder and are better compared to workers who experience stress and are not satisfied with their work. Satisfaction and employee attitudes are important in determining behavior and response to their work. Satisfied employees will commit and work harder to meet organizational goals and provide wholehearted service to the organization by 
the increasing performance that will support organizational effectiveness compared to unsatisfied workers.

If the employee feels satisfied with his job, then this will affect the attitude of the employee's behavior, namely diligent and loving work and caring for the goals of the organization so that the performance becomes better. Job satisfaction can affect employee performance, where employees who work in accordance with the desired goals and feel satisfied with their work, in the end, he will be able to improve overall performance achievements.

This finding is in line with previous research by Khairiyah and Annisa (2013) who found job satisfaction had a significant effect on employee performance. Profita et al (2017) show that job satisfaction influences employee performance. Rahmadita and Susilatri (2004) found that job satisfaction affects employee performance. Rumengan (2011) shows job satisfaction has a direct, positive and significant effect on performance.

\section{Conclusion}

the conclusion of this research are, leadership directly has a significant effect on the work motivation of education and culture department employees in Padang Pariaman, Leadership directly does not have a significant effect on the job satisfaction of the Education and Culture Department staff in Padang Pariaman, Work motivation directly has a sign cant effect on work job satisfaction of the Education and Culture Office staff in Padang Pariaman, Leadership directly does not have a significant effect on the performance of education and culture department employees in Padang Pariaman, Work motivation directly has a significant effect on the performance of education and culture department employees in Padang Pariaman and Job satisfaction directly has a significant effect on the performance of education and culture department employees in Padang Pariaman.

\section{References}

Afsar, B., Badir, Y., Khan, M. M., 2015. Person-Job Fit, Person-Organization Fit, and Innovative Work Behavior: The Mediating Role of Innovation Trust. Journal of High Technology Management Research, 26, 105-116

Alghazo, A. M., and Al-Anazi, M., (2016).The Impact of Leadership Style on Employees' Motivation. International Journal of Economics and Business Administration, 2 (5): 37-44.

Ali, A., Bin, L. Z., Piang, H. J., and Ali, Z., (2016).The Impact of Motivation on the Employee Performance and Job Satisfaction in the IT Park (Software House) Sector of Peshawar, Pakistan. International Journal of Academic Research in Business and Social Sciences, 6 (9): 297 - 310.

Anghelache, V., (2015). A possible explanatory model for the relationship between teaching motivation and job satisfaction, The Edu World 6th International Conference 2014 "Education Facing Contemporary World Issues", 7th - 9th November 2014. Procedia - Social and Behavioral Sciences, 180, 235 - 240.

Arda, M., (2016).The Influence of Transactional Leadership Style and Organizational Culture on Job Satisfaction with Motivation in a Variety of Intervening Variables in North Labuhanbau District Bappeda. http://repositori.usu.ac.id/handle/123456789/663

As'ad, Mohamad. 2002. HR Science Series: Industrial Psychology, Fourth Edition, Yogyakarta: Liberty.

Asghar, S., and Oino, I., (2018).Leadership Style and Job Satisfaction. Market Forces, XIII (1): 1 - 13.

Azar, M., and Shafighi, A. A., (2013). The Effect of Work Motivation on Employees' Job Performance (Case Study: Employees of Isfahan Islamic Revolution Housing Foundation). International Journal of Academic Research in Business and Social Sciences. 3 (9), 432-445

Bungin, M. Burhan, 2010. Quantitative Research Methodology: Communication, Economics, and Public Policy and Other Social Sciences. Jakarta: Kencana.

Chiang, C. F., and Jang, S. S., (2008).An expectancy theory model for hotel employee motivation. International Journal of Hospitality Management, 27 (2): 313-322. DOI: 10.1016 / j.ijhm.2007.07.017 
Dawal, S. Z., Tahaa, Z., and Ismail, Z., (2009).The effect of job organization on job satisfaction among shop employees in automotive industries in Malaysia. International Journal of Industrial Ergonomics, 39, 1-66.

de Jong, J. P. J., and Hartog, D. N. D., (2007). How leaders in fl uence employees' innovative behavior. "European Journal of Innovation Management, 10 (1), 41-64, DOI 10.1108 / 14601060710720546

Fachreza, Musnad, S., and Majid, M. S. A., (2018). The Effect of Work Motivation, Work Environment, and Organizational Culture on Employee Performance and Its Impact on the Performance of Sharia Aceh Banks in Banda Aceh City. Journal of Management Masters in the Faculty of Economics and Business Unsyiah, 2 (1): 115-122.

Gharibvand, S., (2012).The Relationship between Malaysian Organizational Culture, Leadership Style, and Employee Participation Job Satisfaction among MalaysianEmployees from Semiconductor Industry. International Journal of Business and Social Science, 3 (16), 289-298

Gondokusumo, S., and Sutanto, E. M., (2015). Work Motivation, Job Satisfaction, and Employee Organizational Commitments. JMK, VOL. 17, NO. 2, September 2015, 186-196 DOI: 10.9744 / jmk.17.2.186-196

Griffin, Ricky, 2000. Management, Issue 2, Erlangga, Jakarta.

Handoko, Farmer. 2003. Management, Eighteenth Mold. BPFE Yogyakarta.

Handoyo, L. N., Hamid, D., and Iqbal, M., (2015). The Influence of Style On Employees Leadership Performance Through Work Motivation (An Organizational Study at Four Hotels in Malang). Journal of Business Administration (JAB), 22 (1): 1-7.

Haryanto, D., (2017). Effect of Leadership Style, Compensation and Organizational Commitment on Employee Performance CV. Indyferyto Group Yogyakarta. http://repository.upy.ac.id

Hasibuan, Malayu S.P. 2008. Human Resource Management, Jakarta: PT. Earth Literacy.

Hasibuan, Melayu S.P.2010. Basic Management. Jakarta: BumiAksara

Hughes, Richard L, Ginnett Robert C. Curphy Gordon J. 2012, Leadership: Enriching From Experience, Jakarta: SalembaHumanika.

Inaray, J. C., Nelwan, O. S., and Lengkong, V. P. K. (2016).The Effect of Leadership and Work Motivation on Employee Performance at PT. Amanah Finance in Manado. Journal of Scientific Periodic Efficiency, Volume 16 No. 02 of 2016, 459 - 470

Irvianti, L. S.D., Prabowo, R. J., and Permana, G. A., (2012).Effect of Organizational Culture, Leadership, and Work Motivation on CV Surya Raya Employee Job Satisfaction.Binus Business Review, 3 (1): 425 - 435.

Karhs, M. D., and Iskender, H., (2009). 2009. 2009 World Conference on Educational Sciences Procedia Social and Behavioral Sciences 1, 2252-2257.

Kemby, E. F., Tewal, B., and Walangitan, M. D., (2017).The Influence of Leadership, Communication, and Motivation on Employee Performance at North Sulawesi Province BP2RD. EMBA Journal, 5 (3): 3148 - 3159.

Khairiyah and Annisa, N. S., (2013).Effect of Job Satisfaction, Leadership Style, and Work Motivation on Employee Performance at PT Nutricia Indonesia Sejahtera.PESAT Proceedings (Psychology, Economics, Literature, Architecture \& Civil Engineering), 5: 323 - 330.

Khuong, M. N., and Hoang, D. T., (2015).The Effects of Leadership Styles on Employee Motivation in Auditing Companies in Ho Chi Minh City, Vietnam. International Journal of Trade, Economics, and Finance, 6 (4): 210 - 217.

Lututh, Fred. 2006. Organizational Behavior (Interpretation of V.A Yuwono, et al) Edition. Indonesian. Yogyakarta: Andi.

Mangkunegara, Anwar Prabu (2002), Human Resource Management. Bandung: PT. Youth RosdaKarya.

Mangkunegara. (2010). Human Resource Performance Evaluation, Bandung: RefikaAditama

Manulang, M. 2002, Personnel Management, BalaiPustaka, Jakarta.

MartoyoSusilo, 2007, Human Resource Management, Yogyakarta: UGM Faculty of Economics. 
Mas'udFuad 2004, Organizational Diagnosis Survey: Concepts and Applications. Semarang: Diponegoro University Publishing Agency.

Mathis, Robert, L \&Jakson, Jhon, H. (2002).Human Resource Management.Translation. Jakarta. SalembahEmpat Publisher.

Mehta, R., Dubinsky, A. J., and Anderson, R. E., (2003).Leadership style, motivation, and performance in international marketing channels. European Journal of Marketing, 37 (1/2), 50 - 85.

Muhlis, H., (2014). Leadership and Performance of Provincial Government Employee of South Sulawesi, Indonesia: The Influence of Work Capability, Motivation, and Behavior Relationship. Journal of Management Policies and Practices, 2 (1): 97 - 118.

Munir, R. I. S., Rahman, R. A., Malik, A. M. A., and Ma'amor, H., (2012). Relationship between Transformational Leadership and Employees' Job Satisfaction among Academic Staff, International Congress on Interdisciplinary Business and Social Science 2012 (ICIBSoS 2012).Procedia - Social and Behavioral Sciences, 65, 885 - 890.

Mwita, J. I., (2000). Performance Management Model: A System-Based Approach to System Quality. The International Journal of Public Sector Management. 13 (1), 19-37

Olusadum, N. J., and Anulika, N. J., (2018). Impact of Motivation on Employee Performance: A Study of AlvanIkoku Federal College of Education. Journal of Management and Strategy, 9 (1), 53 - 65

Ouyang, Z., Sang, J., Li, P., Peng, J., (2015). Organizational justice and job security as a mediator of the effects of emotional intelligence on job satisfaction: A study from China. Personality and Individual Differences, 76, 147-152.

Prawirosentono, (2012).Human Resource Management. Jakarta: BumiAksara.

Profita, D., Surachman, and Andarwati. (2017). The Influence of Leadership, Organizational Culture, Motivation on Job Satisfaction and Employee Performance at the Government of Lumajang District Government Office (PEMDES). Business and Management Journal, 4 (2): 142 - 152.

Qatmeemalmarhoon, A. B. A. S., Mohdnoor, K. B., Abdalla, M. A. D., and Musbah., A. R., (2017). Effect Of Motivation On Employees 'Performance And Employees' Commitment. International Journal of Management and Applied Science, 3 (9), 39-43

Rahmadita, A., and Susilatri., (2004). Effect of Motivation, Job Satisfaction, Leadership Style, Compensation and Ability on Accounting Staff Performance in Bengakalis Regency Government (Empirical Study in SKPD of Bengkalis Regency). JOM Fekon, 1 (2): October 2014.

Rivai, Veithzal, 2004. Human Resource Management for Companies: From Theory to Practice. PT. Raja GrafindoPersada, Jakarta

Rivai, Vetrizal, and Sagala, Ella Jauvani, 2009 Human Resource Management for Companies from Theory to Practice, Jakarta: Rajawali Press

Robbins, Stephen P, Mary Coulter, 2005, Management, Volume 2, Issue 7, PT. Gramedia Index Group, Jakarta.

Robbins, Stephen P. 2006. Organizational Behavior, Tenth Edition, Jakarta: PT Gramedia Group Index.

Rumengan, G., (2011). Effect of Leadership, Job Satisfaction, Work Motivation and Organizational Commitment on the Performance of Middle Managers at Government Hospitals. Educational Management Scientific Journal, 2 (1): 262 - 271.

Rumondor, R. B., Tumbel, A., and Sepang, J. L., (2016).The Influence of Leadership, Motivation, and Work Discipline on Employee Performance at the Regional Office of the Directorate General of State Wealth Suluttenggomalut. Journal of EMBA, 4 (2): 254 - 264.

Saleem, R., AzeemMahmood, A., and Mahmood, A., (2010). Effect of Work Motivation on Job Satisfaction in Mobile Telecommunication Service Organizations of Pakistan. International Journal of Business and Management, 5 (11): 213-222.

Salutondok, Y., and Soegoto, U.S., (2015).The Effect of Leadership, Motivation, Work Conditions and Discipline on Employee Performance at the Sorong City DPRD Secretariat Office. EMBO Journal, 3 (3) 849 - 862. 
Setiadi, R. U., Setiadi, P. B., and Indroyono, (2016).The Effect of Compensation and Work Motivation on Employee Performance at Semen Indonesia Limited Company. International Journal of Academic Research And Reflection, 4 (3), 64-85.

Shahzadi, I., Javed, A., Pirzada, S. S., Nasreen, S., and Khanam, F., (2014).Impact of Employee Motivation on Employee Performance. European Journal of Business and Management, 6 (23), 159-16

Sharma, M. K., and Jain, S., (2013). Leadership Management: Principles, Models and Theories. "Global Journal of Management and Business Studies, 3 (3), 309-318

Siagian, Sondang P.2009. Human Resource Management, Jakarta: PT. Earth Literacy.

Simamora, Henry. 2005. Human Resource Management. Yogyakarta: STIE.YKPN.

Suttikun, C., Chang, H. J., and Bicksler, H., (2018).A qualitative exploration of day spa therapists' work motivation and job satisfaction. Journal of Hospitality and Tourism Management, 34, 110.

Syafii, L. I., Thoyib, A., Nimran, U., and Djumahir. (2015). The Role of Corporate Culture and Employee Motivation as a Mediating Variable of Fresh Style is related to the Employee Performance (Studies in PerumPerhutani), 2nd Global Conference on Business and Social Science-2015, GCBSS-2015, Bali, Indonesia. Procedia - Social and Behavioral Sciences, 211, 1142 $-1147$.

Thoha, Miftah, 2003, Leadership in Management, Jakarta: PT, Raja GrafindoPersada.

Uno, Hamzah B. 2007. The Theory of Motivation and Measurement. PT. BumiAksara, Jakarta.

Veliu, L., Manxhari, M., VisarDemiri, V., and Jahaj, L., (2017).The influence of Leadership Styles on Employee Performance. Journal of Management, 31 (2), 60-69

Yıldız, S, Baştürk, F., and Boz, İ. T. (2014).The Effect of Leadership and Innovativeness on Business Performance.Procedia - Social and Behavioral Sciences, 150, 785-793. doi: 10.1016 / j.sbspro.2014.09.064

Yuen, K. F., Loh, H. S., Zhou, Q., and Wong, Y. D., (2018). Determinants of job satisfaction and performance of seafarers. Transportation Research Part A, 110, 1-12.

Yusuf-Habeeb, M., and Ibrahim, Y., (2017).Effects of Style Leadership on Employee Performance in Nigerian Universities. Global Journal of Management and Business Research: A Administration and Management, 17 (7) Version 1.0

Zameer, H., Ali, S., Nisar, W., and Amir. M., (2014).The Impact of the Motivation on Employees' Performance in the Beverage Industry of Pakistan. International Journal of Academic Research in Accounting, Finance and Management Sciences, 4 (1), 293-298, doi: 10,6007 / IJARAFMS / v4i1 / 630

Zehir, C., Ertosun, O. G., Zehir, S., and Müceldili, B., (2011). The Effects of Leadership Styles and Organizational Culture Over Firm Performance: Multi-National Companies in Istanbul, 7th International Strategic Management Conference. Procedia Social and Behavioral Sciences, 24, 1460-1474. 